\title{
POLA SEBARAN POPULASI AREN (Arenga pinnata) BERDASARKAN KELAS PERTUMBUHAN di DESA SANGTANDUNG KECAMATAN WALENRANG UTARA KABUPATEN LUWU
}

\section{(Distribution Pattern of Sugar Palm (Arenga pinnata) Population-Based on Growth Level in Sangtandung Village, North Walenrang District, Luwu Regency)}

\author{
Witno $^{1}$ Hadijah Asiz Karim ${ }^{1}$ Megawati ${ }^{1}$ \\ ${ }^{1}$ Program Studi Kehutanan Universitas Andi Djemma Palopo \\ Jalan Puang Haji Daud Nomor 4 Kota Palopo, 19211
}

E-mail : witnosanganna@gmail.com

\begin{abstract}
Aren (Arenga pinnata) is a type of palm where almost all of its parts can be utilized, starting from the roots, stems, leaves, flowers, and fruit. Based on the growth rate of sugar palm can show the pattern of distribution using the Morisita index formula. The distribution pattern is a series that has settled on a symptom itself between individuals, which can be divided into three, namely uniform (regular), random (random), and clustered (clustered). This study aims to determine the distribution pattern of the sugar palm (Arenga pinnata) population based on the growth rate. This research was carried out in Sangtandung Village in July 2021. The data collection method used a purposive sampling technique by placing plots in an area with a sugar palm population following the river body 200 meters long. The distribution pattern of sugar palm based on the growth rate was analyzed using the Morisita index formula. Based on the Morishita index, the study results obtained a pattern of palm sugar distribution based on the growth rate, namely seedlings, saplings, trees with clustered patterns, and poles with uniform patterns.
\end{abstract}

Key words: Distribution Pattern, Growth Rate, Morisita Index, Sugar Palm.

\begin{abstract}
ABSTRAK
Aren (Arenga pinnata) merupakan jenis palem - paleman yang hampir semua bagiannya dapat di manfaatkan mulai dari akar, batang, daun, bunga dan buah.Penentuan pola sebaran aren menggunakan formula indeks Morisita.Pola sebaran adalah suatu rangkaian yang sudah menetap mengenai suatu gejala itu sendiri antara individu - individu yang dapat terbagi tiga yaitu seragam (Regular), acak (Random), dan mengelompok (Clustred).Penelitian ini bertujuan untuk mengetahui pola sebaran populasi aren (Arenga pinnata) berdasarkan tingkat pertumbuhan.Penelitian ini dilaksanakan di Desa Sangtandung pada bulan Juli 2021. Metode pengumpulan data menggunakan teknik purposive sampling dengan menempatkan plot pada areal yang terdapat populasi aren mengikuti badan sungai sebanyak dua jalur sepanjang 200 meter. Penentuan pola sebaran aren berdasarkan tingkat pertumbuhan dianalisis menggunakan formula indeks Morisita.Hasil dari penelitian berdasarkan indeks morisita mendapatkan pola sebaran aren berdasarkan tingkat pertumbuhan yaitu semai, pancang, pohon dengan pola sebaran mengelompok dan tiang dengan pola sebaran seragam.
\end{abstract}

Kata kunci: Aren, Indeks Morisita,Pola Sebaran, Tingkat Pertumbuhan. 


\section{PENDAHULUAN}

Hutan Desa merupakan hutan negara yang dikelola oleh desa dan dimanfaatkan untuk kesejahteraan desa, mengacu pada Undang-undang (No.41/1999 Tentang Kehutanan), khususnya pada pasal 5 ayat 1 . Lalu pada (P.49.Menhut/II/2008)yang membahas peraturan oprasionalnya, hutan desa di artikan sebagai hutan Negara yang dikelola oleh desa dan di manfaatkan untuk kesejateraan desa serta belum dibebani izin/hak.

Aren (Arenga pinnata) merupakan jenis palem-paleman dimana hampir semua bagiannya dapat di manfaatkan mulai dari akar, batang, daun, bunga dan buah(Hasyim et. al. 2013). Selain dapat di manfaatkan sebagai bahan baku industri jenis tumbuhan ini juga merupakan tanaman yang memiliki fungsi konservasi tanah dan air, dimana perakarannya yang dalam dan lebar akan sangat bermanfaat untuk mencegah terjadinya erosi tanah. Terdapat empat jenis pohon yang termasuk dalam kelompok aren (Arenga pinnata). Di antara keempat jenis tersebut yang sudah di kenal manfaatnya dan paling luas penyebarannya adalah jenis Arenga pinnata, yang di kenal sehari-hari dengan nama arena atau enau (Kehutanan 1995). Aren merupakan salah satu jenis tanaman yang pertumbuhannya cepat, dan di Sulawesi selatan jenis pohon ini menyebar di kawasan hutan alam.Pada umumnya, aren di tanam oleh para petani hanya di kebun-kebun saja.Selain itu, jenis ini mudah menyebar dan masuk ke dalam hutan karena buah masaknya banyak di sukai oleh hewan, seperti musang, kelelawar dan babi.

Di Indonesia, luas tanaman aren belum diketahui secara pasti. Menurut(Sebayang 2016), penelitian di 20 kabupaten di Sumatera mendapatkan data luas tanaman aren sekitar 5,29 hektar. Menurut (Ruslan 2017), dari pengolahan data yang dikeluarkan oleh Direktorat Jenderal
Perkebunan (Ditjenbun) tahun 2003

dijelaskan bahwa total areal yang telah

ditanami aren di seluruh Indonesia mencapai 60,482 ha, khusus Provinsi Sulawesi Selatan seluas 7,29 ha. Data terbaru mengenai luas tanaman aren di Sulawesi Selatan masih belum diketahui.

Sebaran populasi aren khususnya pada penelitian ini dilakukan di Desa Sangtandung Kabupaten Luwu.Populasi aren di wilayah ini cukup banyak seiring dengan pemanfaatan nira aren oleh masyarakat sekitar untuk diolah menjadi gula merah.Kondisi ini kemudian mendorong untuk melakukan penelitian terkait pola sebaran aren di wilayah ini dengan melihat kondisi populasinya berdasarkan pada tingkat pertumbuhan aren (Arenga pinnata) yaitu semai, pancang, tiang dan pohon.

\section{METODE PENELITIAN}

Penelitian inidilaksanakan di Desa Sangtandung Kabupaten Luwu selama 1 (satu) bulan yaitu pada bulan Juli 2021.Alat dan bahan yang digunakan dalam peneitian ini yaitu roll meter,Haga Hypsometer, kompas, kamera, abney level, tally sheet, tali rapiah, alat tulis, parang, GPS/Avenza Map. Pengumpulan data dilakukan dengan cara menempatkan plot secara purposive sampling pada lokasi yang terdapat populasi aren di sepanjang pinggiran sungai Sangtandung dengan panjang jalur 200 meter. Jumlah jalur sebanyak 2 jalur.Jarak antara jalur yaitu 30 meter. Pengumpulan data dilakukan dengan cara sensus, yaitu mendata semua populasi aren yang terdapat dalam plot ukuran $20 \times 20$ meter berdasarkan tingkatan pertumbuhan semai, pancang, tiang dan pohon. 

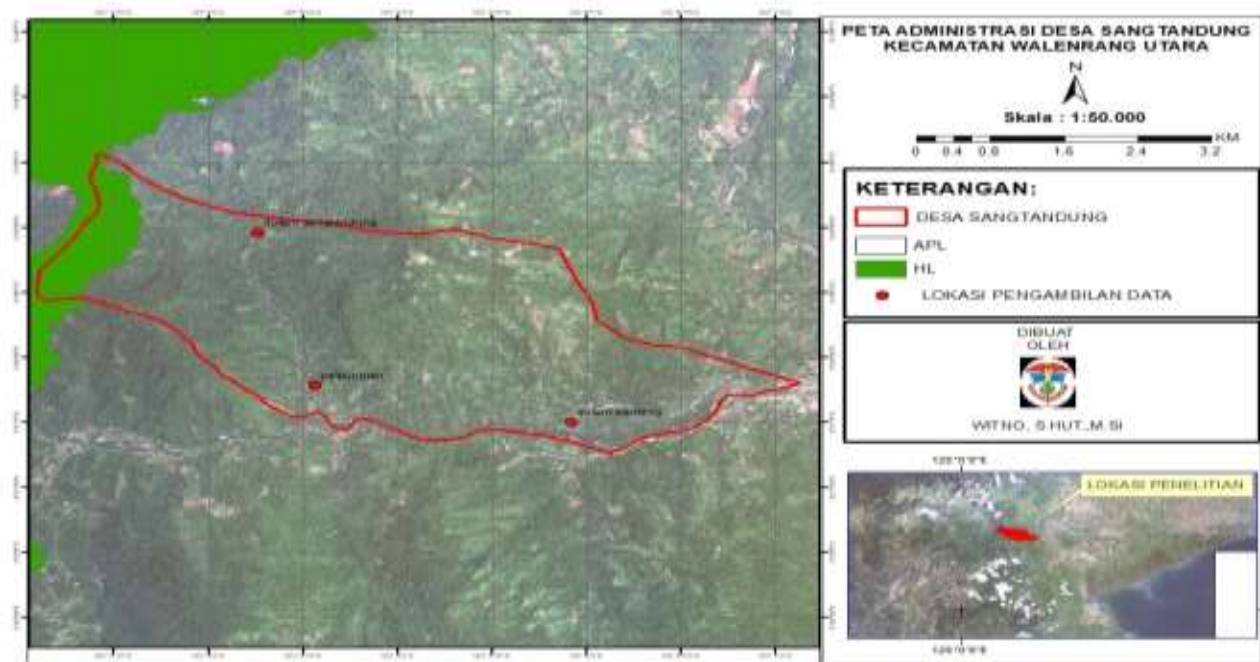

Gambar 1: Peta Lokasi Penelitian

Tabel 1. Syarat Tingkat Pertumbuhan Aren

\begin{tabular}{ccc}
\hline No. & Tingkatpertumbuhan & Tinggibatangbebaspelepah $(\mathrm{m})$ \\
\hline 1. & Semai & $\leq 0,5$ \\
2. & Pancang & $>0,5-1,5$ \\
3. & Tiang & $>1,5-3,0$ \\
4. & Pohon & $>3,0$ \\
\hline
\end{tabular}

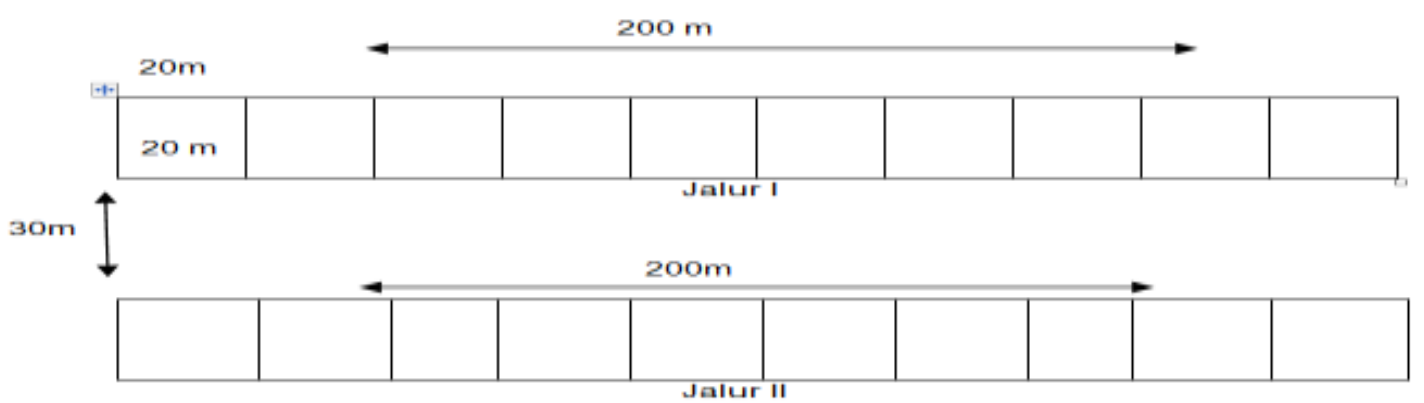

Gambar 2. Sketsa Jalur/Plot Penelitian

Analisis data populasi dengan menghitung jumlah individu setiap tingkatan pertumbuhan yaitu jumlah semai, pancang, tiang dan pohon. Data yang terkumpul dianalisis berdasarkan kerapatan tumbuhan menggunakan rumus dari Odum (1993);(Lomas dan Giampietro 2017) sebagai berikut:

Kerapatan $=\frac{\text { Jumlah total individu }}{\text { Luas petak contoh }}$

Frekuensi $=\frac{\text { Jumlah petak ditemukan suatu jenis }}{\text { jumlah seluruh petak }}$
Penentuan pola sebaran aren menggunakan Indeks Morishita. Indeks ini tidak dipengaruhi oleh luas daerah pengambilan sampel dan sangat baik untuk membandingkan pola sebaran populasi (Utami dan Putra 2020).

$I d=n\left[\frac{\sum x^{2}-\sum x}{\left(\sum x\right)^{2}-\sum x}\right]$

Keterangan:

Id = Indeks disperse morisita

$\mathrm{n} \quad=$ Jumlah plot 
Volume 3 Nomor 2 Desember 2021:12-22

$\sum \mathrm{x}=$ Total jumlah individu suatu organisme dalam plot

$\sum \mathrm{x}^{2}=$ Total dari jumlah individu dalam plot

Besarnya indeks dispers morisita didefinisikan sebagai berikut:

1. Nilai Id $<1$ menunjukan bahwa pola sebarannya seragam.

2. Nilai Id $>1$ menunjukan bahwa pola sebarannya mengelompok.

3. Nilai Id = 1 menunjukan bahwa pola sebarannya acak.

Pola Penyebarannya ditunjukkan melalui perhitungan $\mathrm{Mu}$ dan Mc yang telah distandarisasi (Jongjitvimol et al. 2005)sebagai berikut:

$$
\begin{aligned}
& \left.M u=\frac{X^{2} 0.975-n+\sum x i}{\left(\sum X i\right)-1}\right] \\
& \left.M c=\frac{X^{2} 0.025-n+\sum x i}{\left(\sum X i\right)-1}\right]
\end{aligned}
$$

Keterangan:

$\mathrm{Mu} \quad$ : Indeks Morishita untuk pola sebaran seragam.

$\chi^{2} 0,975$ : Nilai Chi-squre tabel dengan derajat bebas n-1 dan selang kepercayaan $97,5 \%$

Mc : Indeks Morishita (Id) pola sebaran mengelompok. $\chi^{2} 0,025$ : Nilai Chi-square tabel dengan derajat bebas $\mathrm{n}-1$ dan selang kepercayaan $2,5 \%$.

$\sum x i$ : Total jumlah individu suatu organisme dalam plot

n : Jumlah plot

\section{Standar derajat Morishita} (Jongjitvimol et al. 2005) adalah sebagai berikut.

$I P=0.5+0.5\left(\frac{I d-M c}{n-M c}\right):$ Jika Id $\geq M c \geq 1$

$I P=0.5\left(\frac{I d-1}{M c-1}\right):$ Jika $M c>I d \geq 1$

$I P=-0.5\left(\frac{I d-1}{M c-1}\right): J i k a I d>1 \geq M u$

$I P=-0.5+0.5\left(\frac{I d-M u}{M u}\right): J i k a 1>M u \geq I d$

Berdasarkan nilai IP (standar derajat Morishita), maka diperoleh kesimpulan pola sebarannya, yaitu:

a) Jika nilai $\mathrm{IP}=0$, maka individu tumbuhan berdistribusi acak (Random).

b) Jika nilai IP>0, maka individu tumbuhan berdistribusi mengelompok (Clumped).

c) Jika nilai IP $<0$, maka individu tumbuhan berdistribusi seragam (Uniform).
Mengelompok/ clpistered

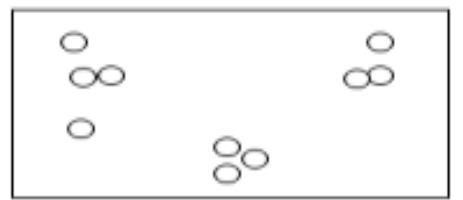

Acak/ random

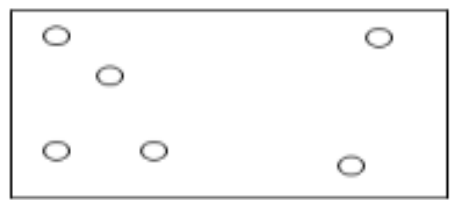

Gambar 3. Ilustrasi Pola Sebaran
Seragam/ regular

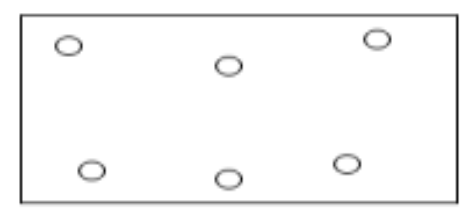




\section{HASIL DAN PEMBAHASAN}

\section{Jumlah Individu Aren (Arenga pinnata) Berdasarkan Tingkat Pertumbuhan}

Berdasarkan tingkat pertumbuhan dari populasi aren menunjukkan bahwa jumlah semai (350 individu)lebih dominan dibandingkan kategori pertumbuhan pada pancang (71 individu), tiang (11 individu) dan pohon (15 individu). Kondisi berbeda pada jumlah individu aren kategori tiang lebih sedikit bila dibandingkan dengan pohon. Kondisi di lapangan menunjukkan lingkungan yang normal, tidak terdapat gangguan berupa aktivitas masyarakat dalam menebang pohon aren, maupun adanya upaya-upaya yang menyebabkan kematian pada semai aren. Diagram pertumbuhan aren berdasarkan tingkat pertumbuhannya menunjukkan adanya persaingan pada tingkat semai dalam memperoleh unsur hara, air maupun ruang untuk tumbuh. Hal ini secara otomatis akan menyebabkan jumlah individu pada tingkat pertumbuhan selanjutnya akan berkurang seiring dengan pertumbuhan pancang, tiang dan pohon (Haryoso et al. 2020). Berikut merupakan diagram tingkat pertumbuhan aren.

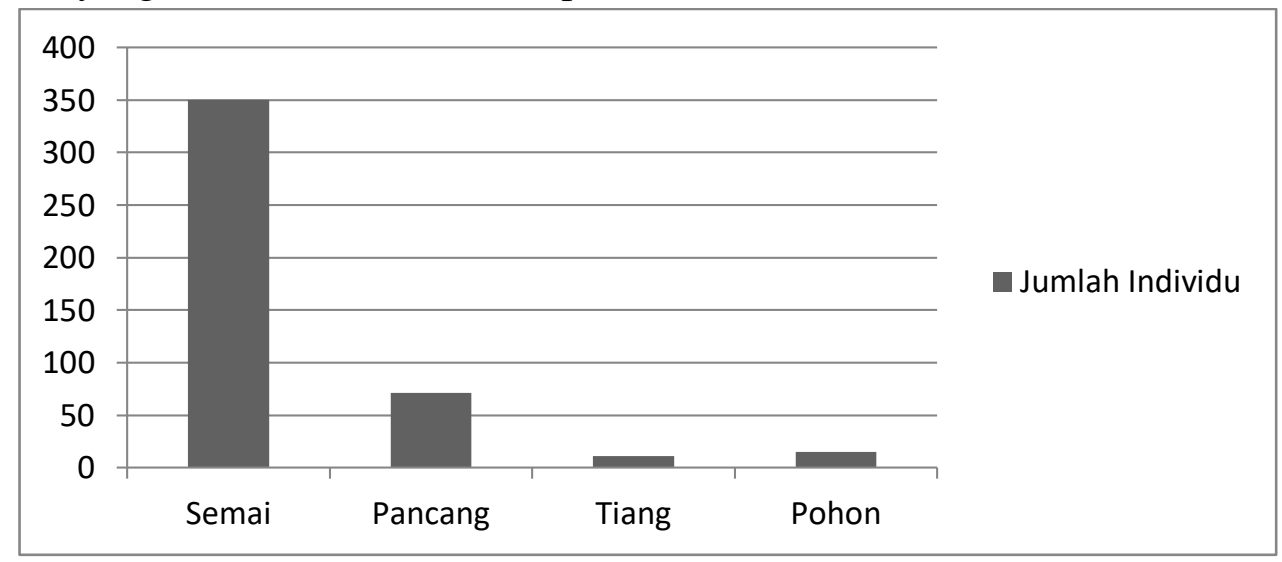

Gambar 4. Jumlah individu aren berdasarkan tingkat pertumbuhan

\section{Kerapatan dan Frekuensi individu aren}

Nilai kerapatan dan frekuensi di atas adalah jumlah individu suatu spesies per satuan luas dengan jalur yang di gunakan. Plot yang digunakan sebanyak 10 Plot/jalur dengan ukuran 20x20. Menurut (Arsyad 2017), besarnya suatu populasi di suatu kawasan tertentu biasanya di nyatakan dalam suatu kerapatan atau kepadatan populasi. Hasil kerapatan dan frekuensi penelitian ini di hitung dengan luas area pengamatan yang berbentuk jalur dan plot. Analisis frekuensi terjadi apabila setiap spesies atau jenis dengan memiliki kondisi wilayah yang berbeda-beda.

Tabel 2. Kerapatan Dan Frekuensi Populasi Aren Pada Seluruh Jalur.

\begin{tabular}{cccc}
\hline Tingkat Pertumbuhan & $\begin{array}{c}\text { Jumlah } \\
\text { (Individu) }\end{array}$ & Kerapatan/Jalur & Frekuensi/Individu \\
\hline Semai & 350 & 0,43 & 1 \\
Pancang & 71 & 0,08 & 0.9 \\
Tiang & 11 & 0,01 & 0.35 \\
Pohon & 15 & 0,18 & 0.35 \\
\hline
\end{tabular}

Dari hasil perhitungan kerapatan tingkat pertumbuhan populasi aren dapat di lihat pada semai, pancang, tiang dan pohon berdasarkan jalur/plot berbeda-beda. Pada 
hasil perhitungan semai mempunyai tingkat pertumbuhan kerapatan tertinggi dengan nilai 0,43 individu/jalur. Pancang memiliki nilai kerapatan 0,08 individu/jalur. tiang memiliki kerapatan 0,01 individu/jalur, dan pohon mempunyai kerapatan 0,18 individu/jalur. Menurut Permentan No.133 tahun 2017 Tentang Pedoman Budidaya Aren (Arenga pinnata), menyatakan bahwa tanaman aren tidak membutuhkan kondisi tanah yang khusus, sehingga dapat tumbuh pada tanahtanah liat, dan berpasir, tetapi aren tidak tahan pada tanah masam $(\mathrm{pH}$ tanah yang rendah).

Kondisi ini dengan nilai frekuensi yang berbeda - beda adalah besarnya potensi ekologi dari pohon aren yang dapat mencerminkan kemampuan menyesuaikan dan dapat beradaptasi dengan baik pada lingkungan, kondisi iklim, (suhu, kelembaban udara) dan tinggi dari tempat permukaan air laut (Victor et al. 2015). Kondisi ini menggambarkan stabilitas tingkat pertumbuhan pada suatu area menunjukan kondisi unsur hara stabil pada areal tersebut.

Data frekuensi di setiap jenis berbeda beda berdasarkan tingkat pertumbuhan seperti semai memiliki nilai frekuensi 1 . Kemudian pancang mempunyai nilai 0.9, tiang dan pohon dengan nilai frekuensi masing-masing 0.35. Frekuensi kehadiran yang rendah tidak selalu memberikan nilai yang rendah dengan jenis lain. Data di lapangan menunjukan bahwa pola sebaran yang terbentuk dipengaruhi oleh adahnya kerapatan dan frekuensi (Sofiah et al. 2013).

\section{Pola Sebaran Populasi Aren (Arenga Pinatta)}

Pola sebaran populasi aren di Desa Sangtandung di tentukan dengan metode indeks morisita yang telah di standarisasi sehingga berpedoman pada nilai (IP). Hasil penelitian menunjukan pola sebaran populasi aren di Desa Sangtandung terbagi dua yaitu seragam dan mengelompok. Pola sebaran yang seragam terdapat pada kelas pertumbuhan kategori tiang. Sementara pada tingkat pertumbuhan semai, pancang dan pohon memiliki pola sebaran yang mengelompok.

Data sebaran berdasarkan tingkat pertumbuhan yakni semai dengan jumlah 350 individu, pancang 71 individu, tiang 11 individu dan pohon 15 individu. Pada ke empat tingkat pertumbuhan ini mempunyai jumlah keseluruhan sebanyak 447 individu. Menurut (Abywijaya et al. 2014) mengungkapkan bahwa komunitas vegetasi dengan penyebaran spesies yang lebih besar akan memiliki jaringan kerja lebih kompleks daripada komunitas dengan penyebaran spesies yang rendah.

Tabel 3. Pola Sebaran Aren (Arenga Pinnata)

\begin{tabular}{ccccc}
\hline Tingkat Pertumbuhan & Id & Ip & $\mathrm{x}^{\mathbf{2}}$ & Pola Sebaran \\
\hline Semai & 7,31 & 1,57 & 32,8523 & Mengelompok \\
Pancang & 0,68 & 0,32 & 32,8523 & Mengelompok \\
Tiang & $-1,13$ & $-0,05$ & 8,9065 & Seragam \\
Pohon & 5,95 & 1,23 & 32,8523 & Mengelompok \\
\hline
\end{tabular}

Berdasarkan Tabel 3. bahwa pola sebaran populasi aren yang terbentuk yaitu pola sebaran seragam (regular) dengan nilai IP $<0$ kemudian pola sebaran populasi mengelompok (clustred) dengan nilai IP $>0$. Adapun tingkat pertumbuhan dari jalur 1 sampai 2 berdasarkan indeks morisita yang telah distandarisasi tingkat pertumbuhan semai dengan nilai IP>1.57 masuk dalam kategori mengelompok (clustred). Begitu juga dengan pancang nilai IP $>0.32$. pohon IP>0.32 masuk dalam kategori pola sebaran mengelompok (Clustred). Berbeda dengan nilai indeks morisita yang terdapat pada tingkat tiang dengan nilai indeks morisita IP<-0.05 dapat di kategorikan dalam pola sebaran seragam (Regular). 
Pola Sebaran Mengelompok Populasi Aren (Arenga pinnata)

Sebaran populasi aren biasanya ditemukan di dekat permukiman, hutan hutan terganggu, hutan tropik kering, hutan tropik basah dan jarang ditemukan di hutan primer. Aren berada pada sisi pinggir hutan yang dekat dengan permukiman, sawah, ladang maupun sungai. Menurut (Muliawan et al. 2016) pola sebaran mengelompok ini menunjukkan kecenderungan yang kuat untuk berkompetisi terutama dalam hal makan dan kondisi tempat tumbuhnya. Selain itu, dapat pula disebabkan oleh kondisi lingkungan maupun tipe substratnya (Hasyim et al. 2013). Menurut (Saleha dan Ngakan 2016), pola distribusi mengelompok diduga merupakan cara beradaptasi dari krustasea khususnya pada semai, pancang dan pohon untuk mengatasi tekanan ekologis dari lingkungan, sehingga organisme cenderung berkelompok pada daerah dimana faktor yang dibutuhkan untuk hidupnya tersedia.

Pola sebaran populasi aren pada, semai, pancang dan pohon memiliki pola sebaran mengelompok. Ini disebabkan oleh dua faktor yaitu faktor lingkungan dan faktor yang berasal dari tumbuhan itu sendiri. Pola penyebaran mengelompok dapat terjadi karena disebabkan oleh kondisi fisik lingkungan yang jarang seragam, meskipun pada lokasi yang yang sempit (Vivi et al.2013). Perbedaan kondisi iklim dan, ketersediaan unsur hara, pada suatu lokasi akan menghasilkan perbedaan yang nyata pada suatu jenis. Menurut (Natalia et al. 2014), faktor lingkungan berpengaruh terhadap pertumbuhan tanaman aren dan juga tidak membutuhkan sinar matahari yang banyak sepanjang hari.

Kondisi lingkungan berbeda dalam suatu wilayah sehingga setiap individu tumbuhan harus beradaptasi dengan lingkungan tempat hidupnya. Jika sesuai dengan kebutuhan hidupnya individu tersebut akan mampu tumbuh demikian pula sebaliknya. Menurut (Wahyuni et al. 2017), menyatakan bahwa pola penyebaran mengelompok terjadi akibat kondisi lingkungan abiotik yang tidak seragam meskipun pada lokasi yang sempit. Di lokasi penelitian aren (Arenga pinnata) memiliki pola pertumbuhan dengan mengelompok terhadap semai, pancang, dan pohon pada kondisi lingkungan yang mendukung pertumbuhannya. Menurut Permentan No.133 tahun 2017 Tentang Pedoman Budidaya Aren (Arenga pinnata), bahwa secara alami pertumbuhan aren berkelompok sehingga ada anggapan bahwa aren membentuk anakan. Hal ini disebabkan buah matang yang jatuh di bawah pohon tumbuh bersama induknya sehinga banyak di jumpai di lokasi penelitian. Hal ini didukung oleh (Susilowati et al. 2019), menyebutkan bahwa pola sebaran spesies umumnya mengelompok sejak benih jatuh di dekat induknya. Jumlah buah yang jatuh disekitaran pohon induk akan tumbuh menjadi anakan kecil seiring dengan kondisi lingkungan yang mendukung. Pada tingkatan pertumbuhan semai aren cenderung mengelompok diperkuat dengan hasil uji morisita dengan indeks nilainya sebesar 1,57 atau IP> 0, yang berarti tergolong dalam kategori mengelompok. Begitu juga pada tingkatan Pancang dan Pohon dengan nilai IP $>0$. 


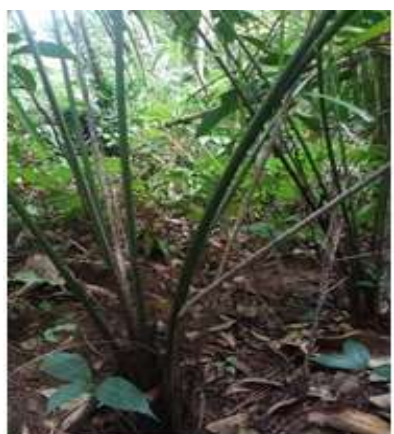

Semai

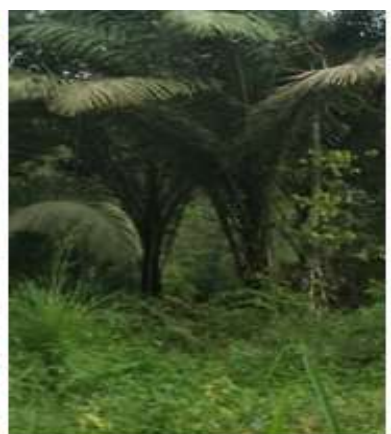

Pancang

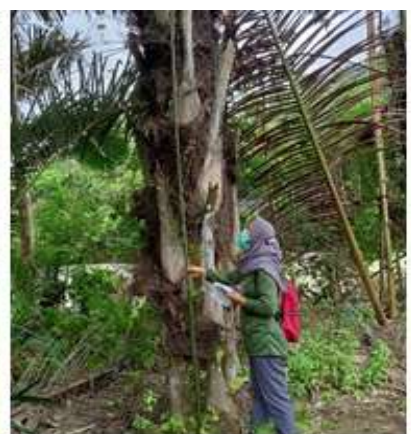

Pohon

Gambar 5. Populasi Aren Pada Pertumbuhan Tingkat Semai, Pancang dan Pohon.

\section{Pola Sebaran Seragam Populasi Aren (Arenga pinnata)}

Aren tumbuh tersebar dan sebagian besar populasinya masih merupakan tumbuhan liar yang hidup subur dan tersebar secara alami pada berbagai tipe hutan (Lempang 2012). Hasil penelitian mengenai persebaran aren menunjukkan bahwa sebaran populasi aren memiliki pola sebaran secara seragam terhadap tiang pada tiap plot dan cenderung berdekatan satu sama lain. Pola penyebaran seragam jarang terdapat pada populasi yang alami. Kondisi ini terjadi apabila terjadi penjarangan akibat kompetisi antara individu yang relatif ketat dengan kondisi lingkungan yang bersifat seragam dan tidak adanya kecenderungan individu untuk bersegresif. Menurut (Zairina et al. 2015) pada umumnya keseragaman terjadi, akibat respon individu terhadap kondisi- kondisi lokal, perubahan cuaca harian atau musiman.

Menurut (Haryoso et al. 2020), pola penyebaran aren dipengaruhi oleh beberapa faktor yaitu ketersediaan makanan, subtrat sebagai habitat hidup, pengaruh faktor

\section{Faktor Fisik Lingkungan}

Secara umum pertumbuhan aren dapat di tentukan oleh lingkungan dimana komoditas itu bertumbuh. Aren merupakan salah satu tanaman hutan yang umumnya tumbuh secara alami tanpa ada usaha budidaya yang dilakukan oleh manusia dan tempat tumbuhnya pada daerah - daerah tertentu saja. Hal ini dikarenakan kondisi ekologi seperti fisika, kimia dan lingkungan serta strategi adapatasi dan interaksi biologis antar populasi yang ada dalam komunitas tersebut. Untuk mengetahui pola penyebaran populasi aren dalam suatu komunitas digunakan perhitungan dengan menggunakan indeks pola penyebaran Morisita dan indeks tersebut diuji dengan menggunakan uji statiska yaitu sebaran Chi Square. Pola sebaran pada tingkat pertumbuhan tiang seragam dibuktikan dengan nilai IP $<0$, yaitu sebesar -0.05 .

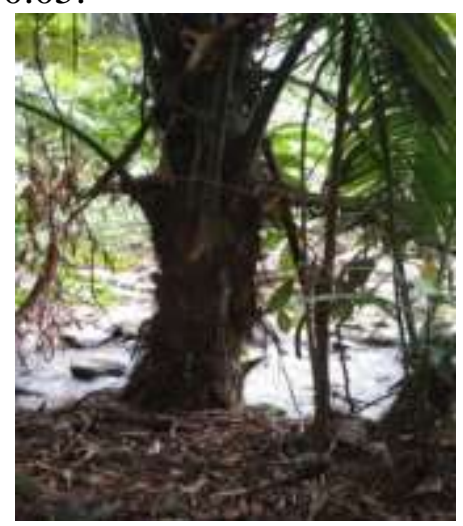

Gambar 6. Populasi Aren Pada Pertumbuhan Tingkat Tiang

fisik dari lahan tempat tumbuh aren memiliki ciri tertentu yang mendukung dalam pertumbuhannya sehingga akan berkorelasi dengan proses pertumbuhanya. Dilihat dari fungsinya, aren merupakan salah satu tumbuhan yang mempunyai fungsi penting bagi lingkungan.

Aren merupakan salah satu tanaman hutan yang umumnya tumbuh secara alami tanpa ada usaha budidaya yang dilakukan 
oleh manusia dan tem-pat tubuhnya pada daerah-daerah tertentu saja. Hal ini dikarenakan aren memiliki kualitas tempat tumbuh tertentu untuk mendukung pertumbuhannya. Hal ini bisa dilihat dari fungsinya sebagai tanaman konservasi, yang menjaga tanah dari proses erosi, dan mempunyai kelebihan yaitu menyesuaikan dengan lingkungan. Pengaruh dari kondisi fisik lahan terhadap pertumbuhan aren pada lokasi penelitian dapat dilihat pada Tabel 4.

Tabel 4. Kualitas Tempat Tumbuh Aren (Arenga pinnata)

\begin{tabular}{cccc|cccc}
\hline $\begin{array}{c}\text { Jalur/Plot } \\
\text { I }\end{array}$ & Kelerengan\% & $\begin{array}{c}\text { Kelembaban } \\
\mathrm{RH}\end{array}$ & $\begin{array}{c}\mathrm{pH} \\
\text { tanah }\end{array}$ & $\begin{array}{c}\text { Jalur/Plot } \\
\mathrm{II}\end{array}$ & Kelerengan \% & Kelembaban & $\begin{array}{c}\mathrm{pH} \\
\text { tanah }\end{array}$ \\
\hline 1 & 1,25 & $20,5 \mathrm{C}^{\circ}$ & 5.0 & 1 & 4,1 & $24,9 \mathrm{C}^{\circ}$ & 6.5 \\
2 & 3,93 & $20,3 \mathrm{C}^{\circ}$ & 5.6 & 2 & 3,82 & $24,6 \mathrm{C}^{\circ}$ & 6.5 \\
3 & 4,14 & $27,4 \mathrm{C}^{\circ}$ & 6.0 & 3 & 6,54 & $26,9 \mathrm{C}^{\circ}$ & 6.0 \\
4 & 5,26 & $27,7 \mathrm{C}^{\circ}$ & 6.0 & 4 & 9,03 & $26,8 \mathrm{C}^{\circ}$ & 6.5 \\
5 & 5,79 & $27,7 \mathrm{C}^{\circ}$ & 6.5 & 5 & 15,02 & $36,9 \mathrm{C}^{\circ}$ & 6.5 \\
6 & 1,14 & $27,8 \mathrm{C}^{\circ}$ & 6.5 & 6 & 4,81 & $27,2 \mathrm{C}^{\circ}$ & 6.0 \\
7 & 4,81 & $27,9 \mathrm{C}^{\circ}$ & 6.5 & 7 & 13,99 & $27,1 \mathrm{C}^{\circ}$ & 6.5 \\
8 & 18,63 & $27,5 \mathrm{C}^{\circ}$ & 6.0 & 8 & 62,03 & $27,3 \mathrm{C}^{\circ}$ & 5.0 \\
9 & 48,35 & $27,3 \mathrm{C}^{\circ}$ & 6.0 & 9 & 3,4 & $27,0 \mathrm{C}^{\circ}$ & 5.0 \\
10 & 47,32 & $26,9 \mathrm{C}^{\circ}$ & 5.6 & 10 & 2,39 & $26,8 \mathrm{C}^{\circ}$ & 5.0 \\
\hline
\end{tabular}

Pengukuran ketinggian tempat dilakukan sebanyak satu kali dalam setiap plot untuk pengamatan yang dibuat. Ketinggian tempat sangat berpengaruh terhadap pertumbuhan, semakin tinggi suatu tempat dari permukaan laut, suhu udaranya akan semakin rendah dan kelembaban akan semakin tinggi. Menurut Bernhard (2007) kelembaban tanah dan ketersediaan air dipengaruhi oleh curah hujan yang cukup tinggi diantara 1.200-3.500 mm/tahun, sehingga berpengaruh dalam pembentukan mahkota bunga pada tanaman aren.

\section{KESIMPULAN}

Kesimpulan dari penelitian ini yaitu populasi aren (Arenga pinnata) terdapat pada semua kategori yaitu semai, pancang, tiang dan pohon. Pola sebaran aren (Arenga pinnata) berdasarkan pada tingkat pertumbuhan terbagi dua yaitu pola mengelompok (Clustered) pada tingkat pertumbuhan semai, pancang dan pohon, sedangkan pola sebaran seragam (Uniform) terdapat pada tingkat pertumbuhan tiang.
Saran untuk penelitian ini yaitu perlunya dilakukan pengamatan lebih detail kaitannya dengan karakteristik tempat tumbuhnya.

\section{DAFTAR PUSTAKA}

Abywijaya IK, Hikmat A, Widyatmoko D. 2014. Keanekaragaman dan Pola Sebaran Spesies Tumbuhan Asing Invasif di Cagar Alam Pulau Sempu, Jawa Timur. J Biol Indones. 10(2):221235.

Arsyad M. 2017. Density and Distribution Pattern of Lotus ( Nymphaea sp .) in Grazing Area of Swamp Buffalo , Pandak Daun Village, Hulu Sungai Selatan Regency. Lemb Penelit dan Pengabdi Kpd Masy. 1:74-79.

Desa P 49/Menhu.-ITH. 2008. Peraturan Menteri Kehutanan Tentang Hutan Desa. Nomor: P.49/Menhut-II/2008. May:1-20.

Febriyanti N, Hikmat A, Ervial D, Zuhud AM. 2017. Etnobotani dan Potensi (Arenga pinnata Merr.) pada Masyarakat Kasepuhan Pasir Eurih, 
Desa SIndanglaya, Kabupaten Lebak, Banten. Media Konserv. 22(2):171-180. https://core.ac.uk/download/pdf/297827 762.pdf.

Haryoso A, Zuhud EAM, Hikmat A, Sunkar A, Darusman D. 2020. Ecological aspects and regeneration of sugar palm in the Sasak community gardens of Kekait village, West Nusa Tenggara, Indonesia. J Manaj Hutan Trop. 26(1):1-12. doi:10.7226/jtfm.26.1.1.

Jongjitvimol T. 2005. Nest dispersion of a stingless bee species, Trigona collina Smith, 1857 (Apidae, Meliponinae) in a mixed deciduous forest in Thailand. Nat Hist $\quad J \quad \ldots .5$ October:69-71. http://www.thaiscience.info/Article for ThaiScience/Article/5/Ts-5 nest dispersion of a stingless bee species, trigona collina smith, 1857 (apidae, meliponinae) in a mixed deciduous forest in thailand.pdf.

Kehutanan D. 1995. Keputusan menteri kehutanan.

Lempang M. 2012. Pohon Aren dan Manfaat Produksinya. Info Tek EBONI. 9(1):3754.

Lomas PL, Giampietro M. 2017. Environmental accounting for ecosystem conservation: Linking societal and ecosystem metabolisms. Ecol Modell. 346:10-19. doi:10.1016/j.ecolmodel.2016.12.009.

Muliawan R, Dewiyanti I, Studi P, Kelautan I, Syiah U, Darusalam K, Aceh B. 2016. Substrat Pada Kawasan Mangrove Di Pesisir Pulau Weh. J Ilm Mhs Kelaut dan Perikan Unsyiah. 1 C:297-306.

Natalia D, Umar H, Sustri. 2014. Pola Penyebaran Kantung Semar (Nepenthes tentaculata Hook.F) Di Gunung Rorekautimbu Kawasan Taman Nasional Lore Lindu. War Rimba. 2(1):35-44.

No.41 U-UTK. 1999. Undang-Undang Republik Indonesia Nomor 41 Tahun 1999 Tentang Kehutanan. Peratur Pemerintah Republik Indones., siap terbit.

Ruslan SM. 2017. Potensi Dan Pemanfaatan Tanaman Aren (Arenga pinnata) Dengan Pola Agroforestri Di Desa Palakka Kecamatan Barru Kabupaten Barru. SKripsi Progr Stud Kehutan Univ Hasanuddin Makassar., siap terbit.

Saleha S, Ngakan PO. 2016. Distribution And Population Structure Of The Juvenile Of Diospyros Celebica Bakh. Under The Canopy Of Their MotherTree. J Penelit Kehutan Wallacea. 5(2):103-111.

doi:10.18330/jwallacea.2016.vol5iss2pp 103-111.

Sebayang L. 2016. Keragaan Eksisteing Tanaman Aren (Arenga pinnata Merr) Di Sumatra Utara (Peluang dan Potensi Pengembangannya). $J$ Pertan Trop. 3(2):133-138. doi:10.32734/jpt.v3i2.2967.

Sofiah S, Setiadi D, Widyatmoko D. 2013. Pada Komunitas Tumbuhan Di Taman Wisata Alam Gunung Baung Jawa Timur * [ Distribution Pattern , Association And Abundance Of Bamboo In Plants Community In Mount Baung Natural Tourism Park East Java ]. Ber Biol. 12(2):239-247.

Susilowati A, Rachmat HH, Elfiati D, Hasibuan MH. 2019. The composition and diversity of plant species in pasak bumi's (Eurycoma longifolia) habitat in Batang Lubu Sutam Forest, North Sumatra, Indonesia. Biodiversitas. 20(2):413-418. doi:10.13057/biodiv/d200215.

Utami I, Putra ILI. 2020. Ekologi Kuantitatif; Metode Sampling dan Analisis Data Lapangan. Yogyakarta: K-Media.

https://www.researchgate.net/publicatio n/344953156_EKOLOGI_KUANTITA TIF_Metode_Sampling_dan_Analisis_ Data_Lapangan/link/60efcef016f9f3130 083f3f8/download

Victor W. Rante Lembang, W. Tilaar TMF. 
Volume 3 Nomor 2 Desember 2021:12-22

2015. Potensi Ekologi, Pola Penyebaran, Dan Pola Pemanfaatan Serat Alam Dalam Kawasan Hutan Produksi Terbatas (Hpt) Gunung Sinonsayang, Provinsi Sulawesi Utara Victor. 5:1-21.

Vivi Atmilia Hasyim, ngakan Putu Oka RIM. 2013. Pola Penyebran dan Regenerasi Alami Aren (Arenga pinnata) di Hutan Alam Palanro Hutan Pendidikan Universitas Hasanuddin. Unhas., siap terbit.

Wahyuni AS, Udi LB, Dan PR, Uhud EAZ.
2017. Population and Distribution Plant Pattern Paliasa (Kleinhovia hospita L.) in Bontobahari District. Media Konserv. 22(1):11-18. doi:10.29243/medkon.22.1.11-18.

Zairina A, Yanuwiadi B, Indriyani S. 2015. Pola Penyebaran Harian Dan Karakteristik Tumbuhan Pakan Monyet Ekor Ranging and Food Composition Plants Of Long Tail Macaque In a Dry Forest In Madura, East Java. J-Pal. 6(1):1-12. 